\title{
After Mining: contrived dereliction, dualistic time and the moment of rupture in the presentation of mining heritage.
}

\author{
Peter Oakley \\ Royal College of Art
}

\begin{abstract}
Since the early twentieth century, attempts have been made to promote sites relating to mining as industrial heritage. Since the rise of the heritage industry in the 1980s, the number and size of the mining sites being managed and promoted as heritage destinations has dramatically increased across the West. This paper will examine how the strategies for interpreting such sites rely on different temporal constructions. As well as outlining the 'technological development' approach and its association with linear time, the paper will unpack the key features of the less understood strategy of 'contrived dereliction' and the dualistic temporal framework that it relies on. This argument will reference a range of mining heritage sites visited and researched by the author: Kennecott, Skagway and Dyea in Alaska, Bodie in California and Geevor in Cornwall. The paper will also identify how curators have used the moment of rupture that can feature in dualistic temporal constructions to promote a specific political viewpoint and consider the social consequences of accepting the dualistic temporal construction that underpins contrived dereliction.
\end{abstract}

\section{Keywords}

Contrived Dereliction; Industrial Heritage; Site Interpretation; Gold Rush; Cornish Mining. 


\title{
After Mining: contrived dereliction, dualistic time and the moment of rupture in the presentation of mining heritage.
}

\author{
Peter Oakley \\ Royal College of Art
}

\section{Introduction}

This paper is concerned with the temporal existence and social importance of mines after they have ceased to be places where minerals are extracted and processed. This may initially appear to be unrelated to the study of working mines and their communities, or an insignificant period in the overall life of any particular mine site. But mining heritage sites can inform an understanding of the social impact of operational, preserved and even proposed mine sites. Closed mines continue to endure as physical entities, and the communities that exist in their vicinity have an ongoing, complex and multi-layered relationship with these industrial relics. All too often, in remarkably similar ways to working mines (see D'Angelo 2012; D'Angelo and Pijpers, this issue), disused mine sites remain stubbornly politically and ecologically charged (Meade 2017).

Any examination of mining heritage sites inevitably involves questions around temporality. What type of past is being evoked? How has the relationship between the present and the past been framed? After mining, how is mining being presented and understood? This paper will consider two very different interpretive strategies employed at mining heritage sites. As well as outlining the 'technological development' approach and its association with linear time, the paper will unpack the key features and some of the implications of the less understood strategy of 'contrived dereliction' and the dualistic temporal framework that it relies on.

This paper utilizes the author's research on and personal involvement with mining heritage, including his work as Heritage and Cultural Tourism Specialist for the South West Lifelong Learning Network(SWLLN) regional development project from 2006 to 2008. The role involved close contact with the Cornwall and West Devon Mining Landscape World Heritage Site's managers, as well as the constituent heritage site managers, marketing managers and site stewards and guides (many of whom were ex-miners). In addition, it draws on field visits to numerous gold mining heritage sites in Alaska, California, Scotland, Sweden and Wales, undertaken as part of the author's Arts and Humanities Research Council (AHRC) funded doctoral 
project (most of these sites have been revisited at least once since). It also uses material gathered during a 2009 field visit to Kennicott in Alaska. The field visits were undertaken alongside archive and library research, including examinations of site management plans, individual site and the overarching World Heritage Site marketing and promotional strategy documents. In the case of the Kennicott site, knowledge of the formal management material was augmented by reading the published outcomes of the Kennicott Oral History Project. Whilst not all the sites the author has visited have been referred to in this article, knowledge of their circumstances has informed the overall argument being presented.

The argument in this paper builds on two previous book chapters written by the author about contrived dereliction: Contrived Dereliction: Employing an aesthetic of decay at mining heritage sites (Oakley 2014) and A Permanent State of Decay: Contrived dereliction at heritage mining sites (Oakley 2015) ${ }^{1}$. These two book chapters were primarily concerned with identifying the key features of contrived dereliction as they manifested at the site, principally from the perspective of the informed viewer. However, though manifestations of time were recognized to be important factors, both in terms of the exploitation of a weathered and distressed aesthetic and the idea of stepping out of the present, a temporal construction was not considered as a constituent element of the concept. The current article redresses this by focusing on the role of temporality in framing contrived dereliction sites as material culture. Firstly, it identifies the dualistic temporal construction that contrived dereliction as a means of presentation both relies on and promotes and, secondly, it unpacks the exploitation of such sites as political instruments (an exploitation that relies on these sites' ability to make manifest and emphasize the moment of transition or rupture inherent in a temporal dualist structure), the current article breaks new ground.

\section{Mining Heritage}

Mining heritage has always been classified as a sub-category of industrial heritage (see: Alfrey and Putnam 1992; Blockley 1999; Douet 2015; Falser 2001; Knapp 1999; Orange 2008, 2015). The consolidation of mining heritage's position as an aspect of contemporary community and national identities also closely follows that of other types of industrial heritage. Sporadic preservation and presentation of mining sites as heritage in the contemporary sense was first undertaken in Western Europe in the early to mid-twentieth century, with growing ambition in terms of both the number and size of sites being explicitly defined and promoted as heritage as the century progressed (Oakley 2015). The rapid growth of a more professionalized 'heritage industry' during the 1980s had a profound effect on the way heritage sites in general were perceived by community leaders and politicians. Sites once looked after by individuals or groups out of personal interest and for no financial reward began to be treated as resources that should be managed according to commercial principles by qualified staff (Harrison 2012; Hewison 1987; Lowenthal 1998, 2015; Wright 2009). Since then, local politicians and regional planners have frequently treated mining 
heritage sites as tourist destinations that hold the potential to underpin local and even regional regeneration initiatives (see Cole 2004; Conlin and Joliffe 2011; Dicks 2000 for examples).

This shift was concurrent with the expansion of World Heritage Site (WHS) inscription criteria to include industrial heritage and efforts to raise the number of industrial sites being inscribed (see Falser 2001; Rodwell 2012). The validation that a WHS appellation gave to a past mining site as heritage, along with optimistic expectations that WHS status would enhance visitor numbers and so generate additional revenue, encouraged site stewards and managers to apply for inscription (Rodwell 2012; for examples, see: Conlin and Joliffe 2011; Robinson and Schneider 2011). Alongside the WHS programme of inscription, other national or federal inscription schemes provide additional or alternative opportunities for stewards to confirm the mining sites they manage as heritage (Council of Europe 2005; European Route of Industrial Heritage 2017; English Heritage 2011; see also Lähdesmäki 2016; Macintosh 1991)

The notion of mining heritage described above has remained predominantly a social phenomenon of 'the West', with the highest concentration of such sites found in North-Western Europe, North America and countries that were formerly Imperial colonies and have a large western settler population (Falser 2001). In the latter case, a notable feature is that they present a distinctly different type of narrative to those in 'the home country', carrying overtones of the pioneering spirit and national emancipation (for a good example in the Australian context see: Evans 1991; Hollick 2011). An enthusiasm for seeing mining sites as comparable to more established categories of heritage destination, such as castles, palaces and religious architecture, is much less evident in southern and Eastern Europe (Edwards \& Llurdes I Coit 1996; Perelli et al 2011; Vargas-Sánchez et al 2011). It is very rarely encountered in the rest of the world, the exceptions usually being outstanding colonial-era mining sites that have achieved World Heritage status inscription, such as Potosí in Bolivia (Flesha 2011; Pretes 2002; UNESCOb 2012).

\section{Heritage Management Strategies}

As part of the heritage sector, heritage mining sites are subject to the same pressures as any other heritage destination. Managers are now expected to maintain the structures and assemblages on their site according to conventions that were developed in the late twentieth century and are now frequently explicitly stipulated in organizational regulations (Blockley 1999; Douet 2015; Weeks 2001). At the same time, managers are also expected to maintain or grow visitor numbers through the provision of suitable facilities and an engaging visitor experience. Visitor numbers are either directly linked to revenue generation through entry fees, or indirectly through grants from the parent organization's central funds, government grants or external bodies, so this is a fundamental aspect of any management post. Alongside this direct commercial imperative, high visitor numbers carry esteem as a key indicator of successful management. These 
pressures, interacting with the peculiarities of each individual site, have led to the adoption of a range of management and presentation strategies.

\subsection{Conservation}

Effectively the ideal of heritage management from a preservation angle, conservation involves making the minimum changes necessary to the physical material, in terms of material interventions and use (see Blockley 1999; Douet 2015; English Heritage 2011). One could claim it is also the most demanding, due to the high expense of maintaining the material fabric and the lack of revenue beyond payments made by, or on behalf of, visitors. In the case of mining heritage, the approach is fundamentally problematic. Mining complexes are usually large and their constituent parts not designed to last. Pithead and processing buildings and the machinery they hold are all too often incremental and contingent responses to immediate needs, rather than elements of any grand overall plan. In addition, the original justification for the existence of any mining complex was the value of the minerals extracted. But continuation of this activity is clearly inimical to the long-term survival of the extant technological systems as material historic records.

\subsection{Restoration}

An alternative approach is restoration: complete repair or replacement of elements of the material fabric and possible alternative reuse. In the early twentieth century, repurposing was an uncontroversial practice at almost any site. Even unique medieval survivals, such as Dartington Hall in Devon, were heavily reconstructed and entirely reinterpreted through imaginative rebuilding programmes (Emery 1970). As industrial sites were incorporated into the heritage cannon at a much later date than churches, palaces, stately homes and castles, their conversion to alternative uses such as living accommodation or offices proved less controversial late into the twentieth century. Examples include the unopposed repurposing of the Victorian warehouses that took place in the 1980s as part of the extensive redevelopment of the London docklands (Docklands Development Organisation 1980).

This type of redevelopment is facilitated by three factors. Firstly, due to their size, industrial buildings such as dock warehouses or industrial factories and mills are expensive to maintain without revenue from use, making them very costly to keep unoccupied indefinitely. Secondly, as they consist of large, regular, empty spaces, they tend to be easy to refit for new uses. Thirdly, their typical location, in the middle of an urban conurbation, adds to the pressure for reuse; the land they sit on is valuable in its own right and many of the potential renters or buyers for the repurposed building live or work nearby.

In contrast, though mining complexes are also often large, their constituent buildings are usually in less convenient configurations for repurposing. In addition, mines have to be sited on geological mineral 
deposits. But the size and purity of any particular deposit, as well as the proximity of that deposit to other resources (existing facilities, skilled and basic labour, transport networks, a suitable power supply and processing materials) and current land ownership are all part of a complicated equation that determines if it would make a profitable mine. So viable mines can end up being remote from large population centers and in inhospitable locations. Where towns have grown up around the mine, the closure usually results in a surplus of building stock, which suppresses the value of any redevelopment. Long-exploited sites also often have the additional aesthetic issues of surrounding spoil heaps and health issues of extensive soil contamination, which further compromise their desirability.

However, though restoration for repurposing is not a typical feature at mining heritage sites, restoration has been employed as an interpretive strategy. A good example can be found in the Alaskan town of Skagway, one of the key staging posts for prospectors during the Klondike Gold Rush of 1897-9 (Emmanuel 1997; Spude 2011). Today, the US National Park Service (NPS) manages many buildings in the historic district of Skagway, as part of the Klondike Gold Rush National Park (National Park Service 2017a). The NPS has restored the interiors of the oldest of these buildings, the Moore Homestead, to recreate their appearance circa 1897-1906, using surviving photographs of the rooms from the period as the primary source (National Park Service 2017b).

\subsection{Abandonment}

Though counterintuitive, abandonment is considered an acceptable strategy within overall heritage management plans. Structures that are considered too problematic or expensive to maintain are sometimes allowed to deteriorate beyond the point of possible resuscitation. The majority of the architectural structures in Skagway's twin town, Dyea (also part of the Klondike Gold Rush National Park), have suffered this fate. In part, the decline of Dyea was a consequence of Skagway becoming the railhead for the interior, combined with the inevitable decline in the valley's overall population once the Klondike rush ran its course. But the town also suffered from periodic flooding from, and destructive changes in the course of, the Taiya river. Dyea has now almost completely reverted to woodland, with only the town's cemetery and the occasional remains of a collapsed log cabin to indicate its existence to hikers.

\subsection{Contrived Dereliction}

There is, however, one peculiar architectural structure left standing from Dyea that does not conform to the abandonment scenario. Walkers taking a specific trail through the woodland encounter a solitary upright storefront. Though the building behind it has gone, and the storefront itself looks on the verge of collapse, it has endured for decades due to careful upkeep by the NPS. A sign tells visitors not to molest the remains and a guard-rope surrounding the structure reinforces this message for the unobservant or forgetful traveler. 
One of the most photographed structures in the region, this surviving remnant has come to represent the pathos of the vanished town.

Dyea is not alone in having an architectural remnant that is surreptitiously maintained. At other mining heritage sites, the extent of such maintenance activity and necessary site policing is much more extensive. The whole of the mining ghost town of Bodie, on the California-Nevada border, is kept in what is described by the site's managers as a state of 'arrested decay'. The town overtly looks in the same dilapidated condition as it did in the 1960s when it was acquired by the State of California. However, this appearance of abandonment has required a long-term programme of surreptitious repair and active policing, undertaken by park rangers who live onsite (DeLyser 1999).

Having recognized the similarity of practice across a range of mining heritage sites (though these were different in avowed intention and descriptive language), in 2014 I coined the term 'contrived dereliction' in an attempt to accurately describe the coexistence of the two, apparently incompatible, aspects of the phenomenon (Oakley 2014, 2015). While, such sites always appear to be abandoned and dilapidated, they are actually being carefully maintained according to defined criteria that admits or privileges an aesthetic of decay.

I originally coined the term 'contrived dereliction' specifically to describe a presentation strategy evident at mining heritage sites. In A Permanent State of Decay, I noted in passing that the same phenomenon was also evident at other types of heritage sites, such as the Haida Village of Ninstints (see Shakley 1998), and reflected that it might be more prevalent than previously recognized. A higher profile site that could also be described as maintained according to the same precepts is the ruin of the industrial exhibition hall in Hiroshima, which since 1945 has been called the Peace Dome. As part of a fraught attempt to memorialize the devastation of the first nuclear attack in war, the city authorities have attempted to maintain the ruined building as it appeared in the immediate aftermath of the bomb's detonation (Takenata 2014).

However, despite the existence of these and other examples of its wider applicability, contrived dereliction appears to be most typically deployed to present mining heritage management. In earlier works, I presented the argument that this was predominantly due to the unusual material nature of this type of site. In the current article I will explore the fundamental relevance of a further aspect: the dualistic temporal frameworks that contrived dereliction sites rely on and promote. How mining heritage sites relate to this and other temporalities is a subject to which we will now turn.

\section{Technological Development, Progress and Linear Time.}


In line with the classification of heritage mining sites as a sub-category of industrial heritage, a common interpretation strategy attempted at heritage mining sites is technological development. This is underpinned by the notion of progress and the tone is celebratory. Each technological 'breakthrough' represented is treated as part of an overall progression, linking the past and present in a simple linear temporal narrative, a perspective that closely relates to the Newtonian linear conception of time (D'Angelo and Pijpers, this issue). Like Newtonian time, the progress narrative also includes a future that follows the same inevitable and measured path. Due to the scientific temporalities that underpin them both, there is a direct relationship between mining heritage museum displays that emphasize technological development and the development-based futures that validate mineral exploration programmes.

In terms of material culture displays, the linear technological development approach tends to abstract individual material elements and offer them to the viewer as fetishized objects. The material manifestation of linear time is the display hall full of cleaned and labeled objects (varying from the minute to the massive) sitting in protective cases, on plinths or behind barriers, and arranged according to their technological complexity/chronological order. The dominant theoretical framing for technological development is the 'industrial revolution'. The heritage industry enthusiastically deploys the term without reservation, despite unresolved disagreements between historians as to its extent or duration as a social phenomenon (whether at a regional, national and global level).

Relying solely on technological development for interpretation at a site comes at a cost. Acknowledging, let alone explaining the relevance of, important social, political and economic events becomes extremely difficult, particularly when these do not fit neatly with technical developments (see Emmanuel 1997; Goody 2012; Goldman 1981; Kesselring, this issue; Spude 2011 for examples). Equally, a technologically based approach can severely underplay the key role of permanent or temporary mining communities in mining as an activity (Engwicht, this issue; Halvaksz 2008; Knapp 1999; Lanzano, this issue; Nevell 2009; Symonds 2005). These lacunae, together with a need felt by key stakeholders or site stewards that these aspects of mining should be either recognized or emphasized, can provide the impetus for employing the alternative presentation strategy of contrived dereliction.

\section{Contrived Dereliction, the 'Lost Past' and Dualistic Time}

In contrast to the linear progression of Technological Development, Contrived dereliction relies on a dualistic construction of time: the time of mining, and the time since mining (which includes the contemporary moment of observation). In contrived dereliction displays, the first period is represented by elements of the material culture of mining. The second period is represented by the 'aesthetic of decay' that situates the practice of mining in the past for the viewer. 
Contrived dereliction sites, with their ruined structures and dilapidated interiors have clear associations with the romantic movement and the picturesque (Edensor 2005; Jackson 1980). Such sites have an evident aesthetic similarity with eighteenth century paintings of ruins and the imaginative follies built in the gardens of contemporary stately homes. All invite the viewer to reflect on the nature of transience. They also share a theatrical aspect, both in terms of their underlying artificiality and their reliance on emotive impact and affect to carry a message. But contrived dereliction is different in being anchored to a specific narrative. It induces or channels a sense of loss in relation to a specific place.

Due to this focus on loss, contrived dereliction is inherently antagonistic to a celebratory, progress-based narrative. This becomes extremely evident when both presentation strategies are being deployed at different parts of the same site.

\subsection{Kennecott Mining Town, Alaska: multiple approaches to presentation}

The company-owned mining town of Kennecott was built in the first decade of the $20^{\text {th }}$ century in the Alaskan wilderness. Operational for 30 years, the town exploited one of the richest copper seams ever found, to the benefit of the syndicate of industrial magnates, including the Havemayer family, Guggenheim family and J.P. Morgan, that developed and owned Kennecott. They provided the immense amount of capital needed to build a fully functioning, modern town, as well as the processing facilities and 196 miles of railroad needed to transport supplies and haul out the processed ore. The syndicate also financed research scientists who developed the innovative ammonia processing technique eventually used on the site. The NPS, which now owns and manages Kennecott as an industrial heritage site, identifies all these achievements in its promotional literature and during guided tours of the site (National Park Service 2012).

In 1938, the declining quality of the ore seams, together with growing competition from new mines in less demanding locations, led to the closure of Kennecott's mines and town itself. The Company's message to Kennecott's inhabitants was curt: "Anyone wanting out must get out immediately. When the last train leaves in two weeks, there will never be another one." To protect the company's property, as the last train left on the $10^{\text {th }}$ November, the rail lines were pulled up behind it.

After Kennecott was abandoned, it spent most of the rest of the century in splendid isolation, its buildings being weathered by freezing winters, glaring summer sun and windblown glacial dust all year round. However, by the end of the century, attitudes towards the town had changed. Once an inconvenient interloper in the middle of a region slated to be preserved as wilderness, and eventually inscribed as a World Heritage Site on that basis (UNESCO 2012c), by the twenty-first century Kennecott had become culturally rehabilitated as an outstanding example of US industrial heritage (see Norris 2005). 
But Kennecott's appeal to visitors also resided in its now-established status as a ghost town. This peculiarity of the site, combined with the practical difficulties associated with any commitment made to restore and maintain its multiple multi-story buildings in pristine condition, meant the management strategy plan for Kennecott chose to encompass all the approaches described previously. Some buildings in Kennecott were selected to be 'rehabilitated', either for interpretive purposes or for alternative uses. Others were to be 'stabilized', retaining an appearance of abandonment whilst being made structurally sound. The rest were either abandoned or demolished (Gilbert et al 2009).

In the planning documents, where intentions are foregrounded, 'stabilization' appears very different from Bodie's 'arrested decay'. In practice, where appearances dominate, the distance is far less. NPS guidelines require that, where possible, the same materials are employed for repairs as originally used in construction and materials are not to be artificially weathered (Weeks 2001). But in an environment where wood and metal are quickly abraded or corroded, within a short time any new additions start to look very similar to the original material. Depending on the ambient conditions, stabilization and arrested decay can produce remarkably similar outcomes. To be fair, NPS conservators are aware of and debate the issue, as well as the implications of their decisions (e.g. DeLong 2008; Norris 2005; Prudon 2010). But the fact remains, for the visitor not versed in conservation practice and alert to the subtle visual cues, the two approaches result in much the same type of aesthetic experience.

Kennecott represents an attempt to juxtapose two presentation strategies built on differing, and incompatible, temporal constructions. But at the site itself, it was obvious that contrived dereliction was the approach that gained more traction with visitors. It seamlessly combined the enchanting visual spectacle of the 'stabilized' buildings with compelling narratives of the time of mining and the dramatic moment of abandonment. These all aligned conveniently with other, established national narratives: the realization of 'manifest destiny' by the US as a nation in the early $20^{\text {th }}$ century; the American pioneering spirit overcoming natural obstacles and hardships in the Western wilderness; and the unstoppable power of capitalist entrepreneurship. There were even echoes of the lost 'Old West' in the 'the last train out' and the ghost town. This was despite the reality that Kennecott's inhabitants had certainly not been independent western frontiersmen in the established sense (it had had actually been a technologically advanced and highly stratified community in terms of its hierarchy, conventions and material culture). But no matter how tenuous, the associations conjured up by contrived dereliction at Kennecott aligned conveniently with the world views of the visitors, who were mostly American, white, middle class or above and middle-aged or old.

\section{Contrived Dereliction and the Captured Moment.}


Apart from being an engaging story, 'the last train out of Kennecott' also fulfils a key role in the overall temporal framing of the site. It represents the moment of rupture between the time of mining and the time after mining. The feeling of authenticity is supported by the event being identified as occurring on a specific day. Its emotive resonance comes from this being a situation that can easily (if not accurately) be imagined by listeners. Almost every adult in the developed world has experienced the anxiety of nearly missing an important train or plane, and so can transpose the memory of that emotion onto the story. In this case, 'the last train out' has become the lynchpin in a dualistic temporal construction. However, in other circumstances, the whole interpretative display is not only constructed around a key moment, but also created in order to explain and valorize it.

\subsection{The Dry at Geevor Tin Mine: politicizing the captured moment}

Geevor is in the parish of St. Just at the tip of the Cornish peninsula in the South West of England. One of the last working Cornish tin mines, in 1991 Geevor was finally completely abandoned and allowed to flood. A small museum, run by the Trevithick Trust, was opened on the site in 1993. In 2001, ownership passed to Pendeen Community Heritage. Soon after, Geevor was identified as suitable for inclusion in a WHS bid focused on local Mining Heritage. The successful application led to it being listed on the Cornwall and West Devon mining Landscape WHS inscription in 2006 (UNESCO World Heritage Centre. 2012a). It has since also been identified as an anchor point on the European Route of Industrial Heritage (European Route of Industrial Heritage, 2017).

In a similar way to Kennecott, different displays in the pithead complex at Geevor use different presentation strategies. The Hard Rock Museum, the most recent addition, describes the local geology and "looks at Cornwall's mining heritage and how mining has shaped the environment and landscape of our County" (Geevor 2017b). This display focuses on a linear narrative of technological development in mining in the region and at Geevor. Visitors can also take a guided tour through the restored horizontal mine workings of Wheal Mexico, one of the nearby precursors to Geevor's multiple, but now inaccessible, shafts and galleries.

One of the oldest displays at Geevor is in the building called The Dry, where miners clocked on and off shift, changed into or out of their work clothes and showered. The changing room in the Dry has been turned into a memorial to the last working day at the mine, with the lockers dressed to appear as if the miners have just finished changing. The passing of time since Geevor closed is evident in the accumulated dust, the obvious deterioration in many of the objects adorning the lockers and the anachronistic fashions and brands of the objects on display. Considering its simplicity, the effect of the assemblage is surprisingly effective in evoking the absent community of miners. The display of objects in the changing room is 
complimented by journalistic style photographs hung around in The Dry, which show Geevor's miners at work, and in The Dry itself.

The creation of The Dry in its current form, as a permanent memorialization of a politically significant moment, defies the linear development narrative of Geevor's later heritage industry displays. The coexistence of linearity and duality at the same site is a case of 'non-synchronicity of mining temporalities' (D'Angelo and Pijpers, this issue) occurring at a single location.

The circumstances surrounding the closure of Geevor heavily influenced the local community's relationship and involvement with the pithead complex as a heritage site. The mine, which had grown to become one of the largest in Cornwall, had been by far the biggest employer in St Just for decades. Geevor's closure was sudden, caused by a crash in the tin price, precipitated by the collapse of the International Tin Council (ITC). The bitterness of the miners' situation was exacerbated by the attitude and actions of the government of day, led by Margaret Thatcher. The Thatcherite policy of following market forces meant the government was ideologically opposed to offering any substantial financial support to struggling mines, even as a shortterm measure (Harris 1986). This policy had been a key factor in a long-running and acrimonious industrial dispute between Thatcher's government and the coal mining unions, which had only just concluded. Having recently won a hard-fought victory over the coal miners, Thatcher's ministers had no interest in putting together a financial rescue package for the struggling Cornish mines.

The more politically committed amongst the Geevor miners felt the lack of government support was a betrayal on multiple levels (The Guardian, 1993). The government had demonstrated it had no interest in safeguarding workers' jobs. The government claiming the financial markets were the infallible arbiter of viability further fueled resentment. This claim was being made despite the fact that it was instability in the market following the collapse of the ITC that had caused the price crash that led to Geevor's closure.

Following Geevor's closure, it was the union representatives who became most active in preserving Geevor as a mining heritage site. It was therefore their perspectives on the closure that coloured the first displays, including The Dry. The Dry now presents Geevor as a social tragedy and expresses loss: loss of meaningful and dignified work; loss of economic security, and loss of community coherence. In this respect, The Dry is both a manifestation of 'dissonant heritage' (Tunbridge and Ashworth 1996) and an illustration of how heritage itself is temporal, articulated in changing politics, ideologies and techniques. The Geevor miners' deployment of an alternative temporal structure to contest the narrative adopted by the mine's owners and heritage professionals is not unique. There are obvious similarities to the strategy employed by the exmining community in Bom Jesus da Serra in the face of a corporate history that denies their lived experience (Mazzeo, this issue). 


\subsection{The social consequences of privileging the captured moment}

The contrived dereliction display at Geevor carries a definite political message, and one that could be claimed to be worth expressing. But the dualistic framing of events in the Dry is, in its own way, as problematic as the idea of linear time and the notion of progress. Viewers, which includes the local population as well as tourists, are encouraged to think of themselves as situated in the 'time after mining'. Though this was the future to those living in the time of mining, it is not a time that has any differentiation in and of itself. It is also entirely defined by absence: the lack of mining. The only meaningful moment in time, the closure, has already occurred. It can only be reminisced upon by those who lived through it, or heard about by those who did not.

For the traveler who can return to an alternative lifeframe, this perhaps provides a salutary moment of reflection. But for the inhabitants of St Just there is a danger of being seduced by, or permanently trapped in, a dualistic temporal construction. The inevitable consequence of this is 'not having a future', a wretched state of being (Augé 2014). The demoralizing effects of internalizing this perspective is evident in many of the comments made by the ex-miners still involved in managing Geevor as a heritage site. A commonly repeated sentence at Geevor is: 'Mining was not just a job; it was a way of life' (Geevor 2017a). The intensity of this claim is matched by the tone of despair in the chorus of the song Cornish Lads, written by Roger Bryant in 1991, the year Geevor finally closed:

Well Cornish lads are fishermen, And Cornish lads are miners too, But when the fish and tin are gone, What are the Cornish boys to do?

The temporal situation of the Cornish ex-miners and their descendants clearly correlates with the circumstances of the people in Mozambique described by Wiegink (this issue). Though not suffering the direct material deprivation suffered by the resettled scraping a living around Tete, the miners' situation fits with Dhillon and Yousef's description of 'waithood' (2009) cited by Wiegink. Similarities exist in terms of 'blocked expectations' and the hope that an opportune but as yet unknown external intervention will rescue them from the current impasse.

There is also a resonance with Askland's 'broken time' as experienced by the landholders in Wollar (Askland, this issue). Her description of the residents' inability to see a future clearly aligns with that found in the Cornish ex-mining communities, though in the latter case it is the rupture caused by the absence of a once-existing mine, rather than the impending expansion of one, that is stealing time. 


\section{Conclusion: After Mining?}

Displays of mining heritage use different approaches to framing, and these approaches rely on different conceptualizations of time. Whilst the 'technological development' approach is underpinned by the notion of linear time, 'contrived dereliction' is built on a dualistic temporal construction. The dualism exists in terms of a 'time of mining' and a 'time after mining'. The material artifacts and structures that constitute the assemblage of a contrived dereliction display come from the time of mining, with the time after mining materialized through the aesthetic of decay that contributes such a powerful emotive aspect to such displays. At sites such as Dyea, the boundary between the two periods is not obvious and does not take a significant place in the site's narrative. At others, such as Kennecott, the shift appears as a specific and sudden moment of rupture. In such cases, this moment can become a key point in the site's heritage narrative. At places such as Geevor Tin Mine, this moment of rupture assumes an even more important position as the rationale for the display.

Contrived Dereliction as a display strategy is ideally suited to convey a sense of loss. Its deployment at the Hiroshima Peace Dome is an attempt to convey the loss of nuclear innocence: prior to 8.15 a.m. on the $6^{\text {th }}$ of August 1945, the world's population was ignorant of the devastation atomic weapons could cause; after that moment, everyone had to live with the possibility of becoming a nuclear target. At Geevor, it is a different type of loss that is the focus of attention: loss of mining livelihoods, personal dignity and a sense of community.

Whilst we now have no option but to live in a Nuclear World, we are not all members of mining or exmining communities. For tourists, the atmospheric, melancholic display in The Dry may prove enchanting, and one suspects, persuasive in convincing viewers of the validity of the political message the miners that created it wanted to convey. The members of the ex-mining community live a different reality, where The Dry promotes a dualistic temporal construction in which they have no option but to live in the 'after-time'; an era defined solely by the absence of mining and which entails the lack of a discernably different future. Local approval of the contrived dereliction display at Geevor may actually be a consequence of a more general acceptance of the dualistic conception of the 'time of mining' and 'time after mining' across St Just and the rest of Cornwall, though where that leaves the sons and daughters of Cornish miners in terms of a future remains an open question.

\section{Acknowledgements}

The field visits to gold mining heritage sites in Alaska, California and Sweden, undertaken in 2009 and 2010, were funded in part by the Arts and Humanities Research Council (AHRC) through the AHRC's 
Doctoral Award Fund. The RCA's Research Development Fund facilitated the author's attendance at the EASA2016 conference in Milan and the EASA Anthropology of Mining SIG workshop held in Utrecht in 2017. The author is grateful to both these funders for their support.

\section{Footnotes}

1. Both these chapters presented arguments developed from conference papers, the first delivered at the European Association of Archaeologists event held in Den Haag in 2010 and the second at the Tourism and the Shifting Values of Cultural Heritage conference held in Taipei in 2013. This paper has indirectly benefitted from discussions with colleagues at these events, as well as directly from presentations given at the Mining Temporalities Panel at EASA 2016 and the EASA Anthropology of Mining network event convened in Utrecht in 2017. The panel and network event were organized by this special issue's editors and attended by some of the other contributing authors.

\section{References}

Alfrey, J. and Putnam, T. 1992. The Industrial Heritage: Managing Resources and Uses. London: Routledge.

Askland, H. (this issue). A dying village: Mining and the experiential condition of displacement. The Extractive Industries and Society. 'Special Issue edited by D'Angelo, L. and Pijpers, R.J. Mining Temporalities: Extractive Industries and the Politics of Time'.

Augé, M. 2014. The Future (translated by John Howe) London \& Brooklyn NY: Verso.

Blockley, M., 1999. 'Preservation, Restoration and Presentation of the Industrial Heritage'. In: G. Chitty and D. Baker (eds.) Managing Historic Sites and Buildings. Abingdon, Oxon: Routledge, 141-156.

Cole, D., 2004. Exploring the Sustainability of Mining Heritage tourism, Journal of Sustainable Tourism 12 (6): 480-94.

Conlin, M. V., and Jolliffe, L. (eds.), 2011. Mining Heritage and Tourism. London: Routledge.

Council of Europe, 2005. Framework Convention on the Value of Cultural Heritage to Society.

D'Angelo, L. 2012. "Capitalismo e risorse minerarie in una prospettiva 'sferica"” [A 'Spherical' Perspective on Capitalism and Mineral Resources], in Rossi, A., D’Angelo, L. (eds.), Antropologia, Risorse e Conflitti Ambientali, Milano, Mimesis, pp. 33-48.

D’Angelo, L. and Pijpers, R.J. (this issue). Mining Temporalities: An Overview. The Extractive Industries and Society. Special Issue edited by D’Angelo, L. and Pijpers, R.J. Mining Temporalities: Extractive Industries and the Politics of Time. 
DeLong,D.G., 2008. 'Changeable Degrees of Authenticity', CRM: The Journal of heritage Stewardship 5(2), 6-14.

DeLyser,D., 1999. 'Authenticity on the Ground: Engaging the Past in a California Ghost Town', Annals of the Association of American Geographers 89 (4), 602-632.

Dhillon, N. and Yousef, T., 2009. Generation in Waiting: The Unfulfilled Promise of Young People in the Middle East. Washington D.C.: Brookings Institution Press.

Dicks, B., 2000. Heritage, Place and Community. Cardiff: University of Wales Press.

Docklands Development Organisation, 1980. London Docklands: the Largest Redevelopment Scheme in Europe.

Douet, J., 2015. Industrial Heritage Re-tooled: The TICCIH Guide to Industrial Heritage Conservation. London: Routledge.

Edensor, T., 2005. Industrial Ruins: Space, Aesthetics and Materiality. Oxford: Berg.

Edwards, J., and Llurdés i Coit, J., 1996. Mines and Quarries: Industrial Heritage Tourism. Annals of Tourism Research 23(2), 341-363.

Emanuel, R. P., 1997. The Golden Gamble. Alaska Geographic 24(2), 1-95.

Emery, A., 1970. Dartington Hall. Oxford University Press.

English Heritage, 2011. Listing Selection Guide: Industrial Structures. London: HMSO.

Engwicht, N. (this issue). "It can lift someone from poverty": Imagined futures in the Sierra-Leonean diamond market. The Extractive Industries and Society. Special Issue edited by D’Angelo, L. and Pijpers, R.J. Mining Temporalities: Extractive Industries and the Politics of Time.

European Route of Industrial Heritage, 2017. ERIH Homepage. http//www.erih.net/ accessed 4/9/17.

Evans, M., 1991. Historical Interpretation at Sovereign Hill. Australian Historical Studies 24(96), 142-152.

Falser, M., 2001. Is Industrial Heritage underrepresented on the World Heritage List? http://whc.unesco.org/archive/ind-study01.pdf. Accessed 31/8/2017.

Flecha,A.C., Knupp,M.E.C.G., Lohmann,G. and Liccardo,A., 2011. 'Mining tourism in Ouro Peto, Brazil: opportunities and challenges'. In: Michael V. Conlin and Lee Jolliffe eds. Mining Heritage and Tourism. London and New York: Routledge, 194-202. 
The Guardian, 1993. Society: Crushing the tin men - 'With hindsight we should have been more militant,' says a former worker in Cornwall's shattered tin mining industry. What lies ahead for Britain's forgotten miners? April 21, 1993, p.12.

Geevor, 2017a. Geevor Tin Mine Museum Homepage. http//www.geevor.com accessed 4/9/2017.

Geevor, 2017b. Hard Rock Museum. http://www.geevor.com/index.php?object=244 accessed 4/9/2017.

Gilbert, C., White, P. and Worthington. A., 2001. Kennecott Mill Town Cultural Landscape Report. http://www.nps.gov/wrst/historyculture/upload/Kennecott\%20CLR\%20Part\%20One.pdf and http://www.nps.gov/wrst/historyculture/upload/Kennecott\%20CLR\%20Part\%20Two.pdf accessed November 11, 2009.

Goldman, M. S., 1981. Gold Diggers and Silver Miners. Ann Arbor, MI: University of Michigan Press. Goody, J., 2012. Metals, Culture and Capitalism. Cambridge University Press.

Halvaksz, J.A. 2008. Whose closure? Appearances, temporality, and mineral extraction in Papua New Guinea. Journal of the Royal Anthropological Institute 14(1): 21-37.

Harris, D., 1986. Cornish Tin Industry. Parliamentary Hansard. Mr David Harris (St Ives) HC Deb 23 May 1986 vol98 cc650-8. Text at http://www.hansard.millbanksystems.com/commons/1986/may/23/cornishtin-industry.html. Accessed on 13 May 2011.

Harrison, R., 2012. Heritage: Critical Approaches. Abingdon and New York: Routledge.

Hewison, R., 1987. The Heritage Industry: Britain in a Climate of Decline. London: Methuen.

Hollick, M., 2011. Sustaining the Benefits of Heritage Mining for Site, City and Region: Exploring the Success of Sovereign Hill Outdoor Museum. In Mining Heritage and Tourism, edited by Michael V. Conlin and Lee Jolliffe, 108-127. London and New York: Routledge.

Jackson, J. B., 1980. The Necessity for Ruins and other Topics. Amhurst: University of Massachusetts Press.

Jones, A.L. and Flynn, K., 2011. Flogging a dead horse or creating cultural capacity? The development and impact of mines as alternative tourist destinations: a case study of South Wales, UK. in Michael V. Conlin and Lee Jolliffe eds. Mining Heritage and Tourism London and New York: Routledge 131-43.

Knapp, A.B., 1999. Social Approaches to the Archaeology and Anthropology of Mining in A.B. Knapp, V.C. Piggott and E.W. Herbert (eds) Social Approaches to an Industrial Past London: Routledge 1-24. 
Kesselring, R. (this issue). At an Extractive Pace: Conflicting Temporalities in a Resettlement Process in Solwezi, Zambia. The Extractive Industries and Society. Special Issue edited by D’Angelo, L. and Pijpers, R.J. Mining Temporalities: Extractive Industries and the Politics of Time.

Lanzano, C. (this issue). Gold digging and the politics of time. Changing timescapes of artisanal mining in West Africa. The Extractive Industries and Society. Special Issue edited by D’Angelo, L. and Pijpers, R.J. Mining Temporalities: Extractive Industries and the Politics of Time.

Lähdesmäki, T., 2016. Politics of tangibility, intangibility, and place in the making of a European cultural heritage in EU heritage policy. International Journal of Heritage Studies. Vol 22 No10. 766-780.

Lowenthal, D., 1998. The Heritage Crusade and the Spoils of History. Cambridge University Press.

Lowenthal, D., 2015. The Past is a Foreign Country: Revisited. Cambridge University Press.

Macintosh, B., 1991. The National Parks: Shaping the System. Harpers Ferry, WV: Harpers Ferry Center. Mazzeo, A. (this issue). The Temporalities of Asbestos Mining and Community Activism. The Extractive Industries and Society. Special Issue edited by D’Angelo, L. and Pijpers, R.J. Mining Temporalities: Extractive Industries and the Politics of Time.

Meade, M. R. 2017. "In the Shadow of the Coal Breaker: Cultural Extraction and Participatory Communication in the Anthracite Mining Region”, Cultural Studies, 31 (2-3): 376-399.

National Park Service, 2017a. Kennecott Mines National Historic Landmark.

https://www.nps.gov/wrst/learn/historyculture/kennecott-mines-national-historic-landmark.htm accessed 03/09/2017.

National Park Service, 2017b. The Kennecott Story

https://www.nps.gov/wrst/learn/historyculture/upload/Kennecottbulletin.pdf. (accessed 03/09/2017).

National Park Service, 2017c. Klondike Gold Rush National Park. https://www.nps.gov/klgo/index.htm (accessed 3/09/2017).

National Park Service, 2017d. The Moore Homestead.

https://www.nps.gov/klgo/learn/historyculture/moorehomestead.htm (accessed 3/09/2017).

Nevell, M., 2009. People versus Machines or People and Machines? Current research Directions within Post-medieval and Industrial Archaeology in Horning, A and Palmer, M. (eds.) Crossing Paths or Sharing Tracks?: Future direction in the archaeological study of post-1550 Britain and Ireland. The Society for Post-Medieval Archaeology Monograph 5. Boydell \& Brewer Ltd: Woodbridge, 31-40. 
Norris, F., 2005. Managing Cultural Resources in Alaska's Parklands. CRM: The Journal of Heritage Stewardship 2(2), 62-78.

Oakley, P., 2014. 'Contrived Dereliction: employing an aesthetic of decay at mining heritage sites'. In: Mike Robinson et al (eds.) Cultural Heritage and Tourism: Engagement and Experience. Taipei: Farterng Culture.

Oakley, P., 2015. 'A Permanent State of Decay: Contrived dereliction at heritage mining sites', in: Hilary Orange (ed.), Reanimating Industrial Spaces, Walnut Creek, CA: Left Coast Press 49-71.

Orange, H., 2008. Industrial Archaeology: Its place within the academic discipline, the public realm and the heritage industry, Industrial Archaeology Review, 30 (2): 83-95.

Perelli, C., Pinna, P. and Sistu, G., 2011. Mining Heritage, Local Development and Territory Identity: The Case of Sardinia. In Mining Heritage and Tourism, edited by Michael V. Conlin and Lee Jolliffe, London: Routledge 203-213.

Pretes, M., 2002. Touring Mines and Mining Tourists. Annals of Tourist Research 29(2): 439-456.

Prudon,T., 2010. 'Esthetics in the Conservation of Building Materials and Finishes', CRM: The Journal of heritage Stewardship 7 (2), 48-50.

Robinson, M. and Schneider, I., 2011. On the Surface: The Heritage of Mines and Mining, Conference Proceedings 14-16 April 2011, Innsbruck, Austria. CTCC (Centre for Tourism and Cultural Change): Leeds Metropolitan University, np. (CD-ROM).

Rodwell, D., 2012. The UNESCO World Heritage Convention, 1972-2012: Reflections and Directions. The Historic Environment: Policy and Practice 3(1): 64-85.

Shackley, M., 1998. Ninstints (Canada): A Deserted Haida Village in Gwaii Hanaas National Park Reserve (Queen Charlotte Islands). In Visitor Management: Case Studies from World Heritage Sites, edited by M. Shackley, 182-193. Oxford and Woburn, MA: Butterworth-Heinemann.

Smith, L., 2006. Uses of Heritage. New York: Routledge.

Spude, R. L., 2011. An Overview History of the Alaska-Yukon Gold Rushes, 1880-1918. In Eldorado!, edited by C. H. Spude, R. O. Mills, K. Gurcke, and R. Sprague. Lincoln, NE: University of Nebraska Press and the Society for Historical Archaeology, 9-24.

Symonds, J., 2005. 'Experiencing Industry: Beyond Machines and the History of Technology', in E. C. Casella and J. Symonds (eds), Industrial Archaeology: Future Directions. Springer: New York, 33-57. 
Takenata, A., 2014. Ruin as cultural heritage: Architectural Survivors of Hiroshima. In: Mike Robinson et al (eds.) Cultural Heritage and Tourism: Engagement and Experience. Taipei: Farterng Culture.

Tunbridge, J.E. and Ashworth,G.J., 1996. Dissonant Heritage. Chichester: Wiley.

UNESCO World Heritage Centre, 2012a. Cornwall and West Devon Mining Landscape. http://whc.unesco.org/en/list/1215 accessed June 5, 2012.

UNESCO World Heritage Centre, 2012b. City of Potosí. http://whc.unesco.org/en/list/420 accessed June 5, 2012.

UNESCO World Heritage Centre, 2012c. Kluane/Wrangell-St. Elias/Glacier Bay/Tatshenshini-Alsek. http://whc.unesco.org/en/list/72 accessed June 9, 2012.

Vargas-Sánchez,A., Porras-Bueno, N. and Plaza-Mejía, Á., 2011. Mining Tourism in the Spanish Province of Huelva. In Mining Heritage and Tourism, edited by M. V. Conlin and L. Jolliffe, London: Routledge. 171-179.

Weeks, K. D., 2001. The Secretary of the Interior's Standards for the Treatment of Historic Properties. http://www.nps.gov/history/hps/tps/standguide/ accessed November 16, 2012.

Wiegink, N. (this issue). Imagining Booms and Busts: Conflicting Temporalities and the Extraction"Development" nexus in Mozambique. The Extractive Industries and Society. Special Issue edited by D’Angelo, L. and Pijpers, R.J. Mining Temporalities: Extractive Industries and the Politics of Time.

Wright, P., 2009. On Living in an Old Country: The National Past in Contemporary Britain [Updated Edition]. Oxford University Press. 